\title{
Types of Households Most Vulnerable to Physical and Economic Threats: \\ Case Studies in Aceh after the Tsunami
}

\author{
Treena Wu
}

Working paper

MGSoG/2007/WP008

2007

Maastricht University

Maastricht Graduate School of Governance 


\title{
Maastricht Graduate School of Governance
}

The 'watch dog' role of the media, the impact of migration processes, health care access for children in developing countries, mitigation of the effects of Global Warming are typical examples of governance issues - issues to be tackled at the base; issues to be solved by creating and implementing effective policy.

The Maastricht Graduate School of Governance, Maastricht University, prepares students to pave the road for innovative policy developments in Europe and the world today.

Our master's and $\mathrm{PhD}$ programmes train you in analysing, monitoring and evaluating public policy in order to strengthen democratic governance in domestic and international organisations. The School carefully crafts its training activities to give national and international organisations, scholars and professionals the tools needed to harness the strengths of changing organisations and solve today's challenges, and more importantly, the ones of tomorrow.

\author{
Author \\ Treena Wu, PhD fellow \\ Maastricht Graduate School of Governance \\ Maastricht University \\ Email: treena.wu@governance.unimaas.nl
}

\author{
Mailing address \\ Universiteit Maastricht \\ Maastricht Graduate School of Governance \\ P.O. Box 616 \\ 6200 MD Maastricht \\ The Netherlands \\ Visiting address \\ Kapoenstraat 2, $6211 \mathrm{KW}$ Maastricht \\ Phone: +31 433884650 \\ Fax: +31 433884864 \\ Email: info-gov@governance.unimaas.nl
}




\section{Types of Households Most Vulnerable to Physical and Economic Threats: Case Studies in Aceh after the Tsunami}

\section{Introduction}

The special administrative territory of Aceh, formally known as Nanggroe Aceh Darrusalam (NAD) established in 1956, is divided into 8 districts, 2 municipalities, 2 administrative cities, 131 sub-districts, and 5,349 desa (villages). The population is estimated to be 4 million inhabitants. The main ethnic groups are Acehnese, Gayonese, Alas, Tamiang, Simelu, Ulu Singkil, Aneuk Jame, and Kluet. Since its resistance to Dutch colonisation in the late 19th century Aceh has been no stranger to violence and conflict. In 1959, the Special Region (Province) of Aceh (Daerah Istimewa Aceh) was established with autonomous governance in religion, education, and culture. In the following decades, Aceh saw the extraction of its natural resources, most notably oil and natural gas. The Free Aceh Movement (abbreviated as GAM), was created in 1976 with the purpose of freeing Aceh from Indonesian (Republik Indonesia or RI) rule, and became the raison d'être for heavy military presence in the province. From 1976 - 2005, there was conflict between the military (Tentera Nasional Indonesia) and GAM until the Finnish brokered peace accord was signed. An estimated 15,000 people died as a result of the RI-GAM conflict.

On December 26, 2004, an earthquake struck $150 \mathrm{~km}$ off the coast of Aceh. Forty-five minutes later the tsunami wave hit Aceh and within minutes it swept clean an $800 \mathrm{~km}$ coastal strip of Aceh. Some 130,000 people were killed and 37,000 remain missing. The March 28 earthquake added to the toll in Nias, Simeulue and southern parts of Aceh. This exacerbated the damage from the tsunami. The December earthquake caused the $2000 \mathrm{sq} \mathrm{km}$ island of Simeulue, with its 78,000 inhabitants, to sink about one meter, while the March earthquake caused it to rise two meters more, in some parts.

These events caused immense social, economic and environmental devastation to areas that were already poor. Before the tsunami, more than a third of the population of Aceh lived in poverty. Now, almost half live below the poverty line or are dependent on food aid. In Indonesia, the poverty line is defined according to the total expenditure required to purchase a diet consisting of 2,100 calories per day, or the "food energy intake method"1.

This paper identifies and describes one of the types of households vulnerable to physical and economic threats in Aceh which had experienced over 30 years of civil conflict and the tsunami. This study will be carried out in the context of emergency and relief aid and local efforts to cope with risk. The type of household being described is one living below the poverty line and with the presence of at least one migrant worker family member. This hypothesis has been made in response to many observers who claim that certain socio-economic groups are particularly vulnerable to shocks (see Cornia et al. 1987 and World Bank, 1990 inter alia). Yet there is very little research on exactly who is vulnerable or why they are vulnerable. Rigorous vulnerability analysis using cross-sectional household surveys and panel data are especially rare to carry out in the context of a natural disaster and civil conflict. As a substitute, the use of area specific fieldwork to collect case studies is carried out.

To develop this hypothesis, firstly consider that there has been a long term presence of migrant workers (formal government classification of Tenaga Kerja Indonesia, TKI - males and Tenaga Kerja Wanita, TKW - females) in the neighboring countries of Malaysia and Singapore who send home remittances. These workers prefer to be located in these two countries because of proximity 
to Aceh and similarity in culture. There are an estimated 527,000 contract workers and 500,000 illegal workers based on various sources (ESCAP, 1985; Malaysian Bureau of Immigration, 1992; Wong, 2002). However it is difficult to verify these numbers because of the lack of data on migrant flows especially for illegal workers. Given the magnitude of these estimates, it is then very possible that the size of this socio-economic group is significant. Secondly, to turn conventional wisdom on its head, these migrant workers who are helping to diversify household income can actually increase household vulnerability after a natural disaster. This is because of the breakdown of physical and financial infrastructure for the transfer of cash and other resources to their families.

1 Indonesia Badan Pusat Statistik

\section{Analytical Framework}

Poverty concerns one's current socio-economic status, while vulnerability focuses on changes in socio-economic status. Vulnerability is a dynamic concept, involving a sequence of events after a shock such as a disaster that can either be man-made or natural. A shock has two components, 1) an economic shock and 2) a social services shock (Glewwe and Hall, 1998). Conditional on a disaster, the social services shock component is larger because of the breakdown of physical and economic infrastructure. Emergency and relief needs such as food, water, medicine and clothing cannot be easily met. In the short-term, there are reductions in direct government provision of goods, services and income transfers. Given this failed infrastructure, it is expected that in the short term, diversified sources of household income from family members who are migrants should also be affected. This should increase the vulnerability of households living below the poverty line. It is assumed that this type of household is operating within the unitary household model where there is the pooling of resource use (Becker, updated 1991).

This hypothesis contrasts from Glewwe and Hall (1998) who reason that some households are more susceptible to economic shocks because of less diversified household income. Just as diversifying investments, enables one, conditional on some level of risk, to attain higher (expected) returns, households with several income sources, such as different occupations, can reduce their risk to major drops in income. Smaller households, with fewer working age members, are less able to diversify and thus more vulnerable. The opposite of this logical reasoning may be correct because the diversified source of income comes from an area that is geographically different from the disaster.

While Glewwe and Hall are addressing an important limitation in the economic literature about which socio-economic group is vulnerable to shocks and why, this paper will attempt to push the boundaries further. This will be done by analyzing the allocation of income within the household. Because of the lack of information on the within-family distribution of income, poverty concepts still overwhelmingly pertain to family or household units (Lazear and Michael, 1988). For practical purposes the assumption is implicitly made that income is distributed uniformly within the family. A family unit is designated as either "in poverty" or "not in poverty" and then either "vulnerable" or "not vulnerable". However it can be a very different story, if a family unit is not living under the same roof and at least one family member is located in a different economic and geographic area. This affects the flows of income between people within households. This situation clearly applies to many Indonesian families particularly the Acehnese and their socioeconomic mobility patterns.

Graeme (1982) first defines the mobility patterns in Indonesia as circular migration, nonpermanent economic movements from one area to another. Circular migration is based on a continuing, long term and fluid relationship among countries that occupy what is now 
increasingly recognized as a single economic space (Agunias and Newland, 2007). But when a single economic space is interrupted by a disaster e.g. the tsunami and civil conflict, intrahousehold income transfers are also disrupted. Telecommunications are down. Transportation routes are damaged or destroyed. Families are killed and / or displaced from their villages. Individuals disappear. As such this type of household has a higher level of vulnerability.

\section{Methodology}

To examine migrant household vulnerability to disasters, the research questions in this paper are: 1. How are households with migrant workers vulnerable to natural disaster and civil conflict?

2. Which household member benefits from the migrant household member's remittances?

Or do all household members benefit?

3. Do remittance patterns change in the period of emergency and relief? By how much? What are the channels used? Are these channels formal (private and public) or informal?

The rest of the paper is organized in the following way. Section 4 is the departure point of enquiry describing the mobility trends of Indonesian migrant workers in general followed by section 5, the specific trends of Acehnese migrant workers. How these workers move, either through legal or illegal channels and where they work affect how often and how much that can be sent back home to families. Studying Indonesia country level migration and remittances trends are needed for inferences to be made about the Acehnese situation because of the lack of data available stemming from the past conflict. Section 6 will discuss the possible correlations between the tsunami, migration trends and remittances sent to Aceh. Section 7 provides the conclusions.

Area specific fieldwork covered the north east coast of Aceh on one side of the Strait of Malacca and the west coast of Malaysia on the other side (Figure 1). Primary data was collected based on individual and focus group semi-structured interviews with 29 migrant workers and / or their families in Aceh. The sampling method used was non-random snowballing because of the sensitive nature of questions asked about a family's finances. Attempts were made to ensure the sample group was split urban (13 respondents) - peri urban (6 - respondents) - rural (10 respondents) and male (21 respondents) - female (8 respondents). 
Figure 1

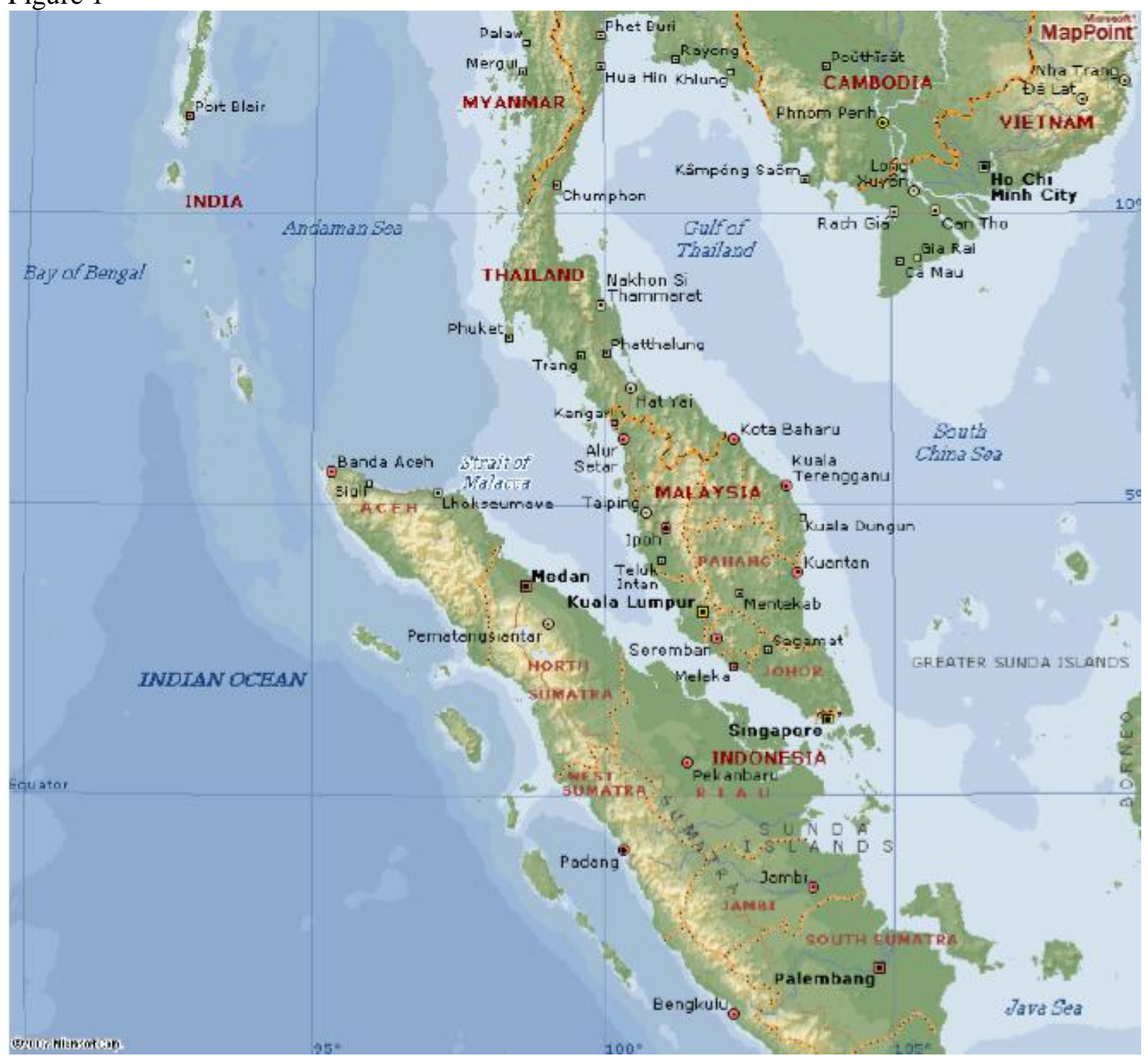

Interviews with six migrant worker union organizers and community leaders have been included. These interviews will help to increase the validity and reliability of conclusions made to enable some generalization. To complement the migrant worker interviews, there are semi-structured interviews with seven remittance sending companies in Aceh, Malaysia and Singapore including Western Union. These companies provided a perspective on the remittance channels and whether it was affected in the aftermath of the tsunami as well as the pre and post tsunami remittance patterns. In terms of triangulation of data, there is an analysis of secondary data comprising of macro-level and micro-level studies carried out by migration and economic researchers, migrant worker recruitment practices, Bank Republik Indonesia reports, commercial banking reports and postal authority reports.

\section{Migration Trends \& Remittances in Indonesia}

This section will describe how workers in Indonesia generally migrate, the system of recruitment used and the motivation for migration - remittances. 


\subsection{Migration \& Wages}

The top destinations for migrant workers are Malaysia and Singapore. Other destinations include the Middle East. This is because of the geographical proximity between Indonesia and these two countries, similarities in culture and the existence of social networks in the destination countries. The labor supply chain that starts with the sourcing of labor that is then transported to Malaysia and Singapore is well established. This supply chain is managed by a series of middlemen and brokers (locally known as calo). The type of labor that is needed tends to be low skilled and is used to meet the needs of the mining, plantation, construction and domestic work sectors. These migrant workers come largely from the agricultural sector. But because of the gains made from technological advancement in this sector, there is less need for agricultural labor (Hugo, 1995).Unfortunately non-farm activities are limited leaving many of these workers unemployed. Because of the higher rates of economic growth in Malaysia and Singapore, there are more employment opportunities for these workers. Furthermore, the wages paid in these destination countries are much higher than in Indonesia (Hugo 1993, Jones 1996). A migrant worker can be recruited for employment following two methods 1) with the help of relatives in the destination countries or 2) by employers / employment agencies in the different sectors.

\subsection{Social Network Recruitment}

Old pioneering migrants who are settled are a very important source of job information for new migrants. In addition new arrivals in Malaysia or Singapore are initially settled by the pioneers, and they are also very instrumental in seeking jobs for the new comers. This is mainly because there is a social network in terms of a strong blood relationship between the new and the old migrants (Salt, 1987; Boyd, 1989; Mantra, 1997).

\subsection{Employment Agencies}

The employer or employment agency initiates the recruitment process. This type of recruitment is used by Malaysian or Singaporean employers who urgently need to fill positions in factories and plantations. A premium is paid and this provides an incentive for recruiting agencies and brokers officially licensed by the Indonesian Ministry of Manpower to as likely send migrants illegally as their unlicensed counterparts (Jones, 1996). However the consequence is that the migrants urgently recruited tend to enter on a tourist visa and when the visa expires, the workers are likely to be caught, detained and deported; this after having mortgaged land or taken out loans from local moneylenders at 100 percent interest or higher to pay the recruiter's fee in the first place (Jones, 1996). This was verified by a man interviewed in Lamno, Aceh. He had made two attempts to become a migrant worker. He sold all his household assets in order to pay for the recruiter's services as well as to buy a counterfeit passport. Upon arriving in Malaysia he was arrested and deported. His remaining asset for collateral, land was destroyed in the tsunami and he is now struggling to look for work as a driver. Based on interviews with other migrant workers, the average cost for travel papers (legal or illegal) now is a cost prohibitive Rp6 - 7 million or approx. US\$600 - 700 .

\subsection{Remittances}

The rationale for labor migration is to improve economic welfare. Therefore, the household economic dependence on the remittances made by migrants is very high. Most of these low skilled workers follow a circular migration process. They tend to take employment on a single short-term, repeated short-term such as repeated two year contracts in factories or seasonal basis. Many view the employment as short term because they would like to be quickly reunited with their families once they have made money. These remittances can be in the form of money, property or ideas (skills) usually carried by the returnee migrants to their places of origin (Mantra, 
1997). Main areas of spending are repairing or building a home, sending one's children to school or purchasing agricultural land (Rudnyckjy, 2004). However such spending is adjusted to the unpredictable nature of remittances - migrants will send money home only when they have paid off their debts to agents and have some savings.

One of the problems encountered in computing or estimating how much remittance is made by these migrants is the uncoordinated nature of remitting. On average remittances make up $20 \%$ $50 \%$ of a migrant's income (Orozco, 2005). The value of remittances can range from the equivalent of US\$25 - 75 (Kompas, 30/10/2004; New York Times, 26/3/2006). Although these amounts seem negligible, they have an income redistribution effect and go a long way in supporting the livelihoods of families in Indonesia. These amounts can help prevent families from falling into chronic poverty or minimizing the incidence of transitory poverty.

\section{Migration Trends \& Remittances in Aceh}

\subsection{Migration}

While the national migration trends and the remittance patterns are similar in Aceh, there are two main differences. First, while most Indonesian migrants take on short-term work contracts, Acehnese migrant work is characterized by both short-term and long-term work. Long-term work increases the ability of workers to keep sending remittances home. Second, migration and remittances have been strongly influenced by the RI-GAM conflict. Acehnese society was continuously in conflict to varying degrees for over 30 years. How they coped is reflected by migration trends and how the remittance corridor has developed over time. The same type of risk management has been used in response to the tsunami.

There are permanent Acehnese settlements in Malaysia and Singapore. Migration was not solely motivated by economics and redistribution. They migrated for different reasons - trade, education, religion and politics particularly the conflict. The implication is that the social network for Acehnese migrant workers is much stronger than for other Indonesian workers. The settlers become an important source of information and support for new arrivals.

During fieldwork, the presence of a social network was found in an Acehnese community located in Selayang, near Kuala Lumpur the capital of Malaysia. The size of the community is about 500 people. This is a low income, peri-urban area that functions as the wholesale market for fresh produce sold to the city. Wholesale trading activities here used to be controlled by Malaysians but this is gradually changing because of the entrepreneurial spirit of the Acehnese. This community in Selayang comprises of Acehnese people with origins exclusively from Pidie, Bireun and Lhokseumawe. They will only protect the interests of those from the same area of origin. In interviews with community leaders, this group has been in existence since the beginning of the conflict. According to them, there are other similar communities in the Klang Valley, Penang, Malacca and Johor. Community leaders explained that they have been assisting in the relocation of undocumented migrants, mostly men, from the same areas of origin in order to escape political persecution. This assistance was also provided in the aftermath of the tsunami when some internally displaced people (IDPs) did not know if the security situation in Aceh would stabilize. Once they have entered this community, the migrants receive assistance in looking for housing and work on construction sites or increasingly at the wholesale market. Since the RI-GAM peace agreement, some families have started to return to Aceh.

The Aceh migrant workers in Malaysia and Singapore are concentrated in urban and peri-urban areas. Based on interviews, there is specialization of work and this is distinguished by gender. 
The TKI or males tend to work in construction, factories and trading. The TKW or females tend to work in factories. In the interview responses it was found that the TKI tended to accept work in the informal economy and risked arrest and deportation. On the other hand, the TKW tended to work in the formal economy and as such experienced less vulnerability because of unstable employment. This distinction is related to education levels and qualifications required for formal work. In the interview responses, the TKI tend to be less well educated than the TKW who all have at least a high school education. This is associated with the civil conflict where males were targeted and many could not complete their education. Another distinction that was found was that the TKI tended to take on unpredictable short-term work while the TKW signed job contracts for two years that could be renewed. Many TKW tend to be between $18-30$ years, work up to five years in factories, accrue more savings for remittances and / or small scaled investments and then return home to Aceh to marry and have children.

Based on interviews, the wages earned in the different types of work:

Table 1

\begin{tabular}{|l|l|}
\hline Type of Work & Monthly Wage (US\$ equivalent) \\
\hline Construction & $400-530$ (depending on skills level) \\
\hline Factory & $114-530$ (if including overtime) \\
\hline Trading & 320 (average income) \\
\hline Services - bakery, restaurant, cleaning & $186-213$ \\
\hline Domestic Maid & $133-213$ \\
\hline Plantation & 106 (average income) \\
\hline
\end{tabular}

\subsection{Remittances}

Because of the social network and the number of repeated short-term contracts, the size of remittances sent to Aceh is potentially larger than in other regions of Indonesia. However this is difficult to verify. This is because during the conflict, there was a lack of data collected. Also according to a respondent who was a GAM soldier, the system for migration and remittances was fine-tuned for use in the informal economy. This was because of a deep sense of distrust and suspicion of the government. Hence there is the unwillingness to have data recorded officially. Case in point is that the official statistics from the Aceh Department of Manpower (Dinas Tenaga Kerja Aceh) reported that in 2004 there were only 150 migrants workers and in 2005 only five workers; minimum remittances were reportedly sent. The question then is how to trace the remittance corridors or channels.

In general remittance channels can be categorized as formal and informal:

Formal Remittance Channel

Formal banks in Malaysia such as Bumiputera-Commerce Bank (BCB), Rashid Hussein Bank (RHB) and Malayan Banking provide remittance sending services using telegraphic transfers (TT) or international banker's cheques. In Indonesia, banks such as Bank Internasional Indonesia (BII), Bank Nasional Indonesia (BNI), Bank Rakyat Indonesia (BRI), BUKOPIN, Danamon and Bank Syariah Mandiri provide remittance receiving services The recipient must have a bank account. The time needed for the transfer to reach a recipient in an isolated area can be up to two weeks. This is because the receiving bank branch is located in a town and the recipient from a village has to arrange for transportation to go to the bank to withdraw the funds. But now banks 
like BNI and BRI are expanding to rural areas. These services tend to be used by formal migrant workers with a higher level of education who demand secure transactions and who are less price sensitive to the commission fees. In addition they have a higher level of consumer awareness of the benefits and costs of using these services. There is a scale of commission fees that increases with the amount sent. The fees are considered to be expensive. The migrant workers usually compare costs in their heads, with the price of rice in Aceh - USD 90 cents.

Another formal channel is Western Union (WU) financial institution where the recipient does not necessarily have to have a bank account. The transfer is made within minutes. The sender receives a Money Transfer Control Number (MTCN - used by WU as a condition for disbursing funds). Either the sender or WU will contact the recipient (in writing / for additional fee by phone) to inform him / her of the transfer. Agents are only located in the main towns of each district in Aceh. Alternatively WU will function like a bank and transfer the funds to the recipient's bank account. Because of the same function, many formal banks are WU agents. The scale of commission fees that increases with the amount sent is relatively expensive. At the lowest point of the scale for its operations in Malaysia, the fee is US\$5 which is $2 \mathrm{x}$ more than the informal remittance channel.

For the un-banked, another formal option available to them is to receive a money order (Wesel $P O S$ ) where the sender will inform the recipient of a personal identification number to be used at the receiving post office for redemption. Alternatively, the un-banked with proof of identification or a letter from the sender will receive a cash disbursement from the post office. According to Pos Indonesia reports Wesel Pos is the most popular system of remittance2. But Wesel Pos appears to be less popular with the Acehnese as only one respondent used it. In interviews, it was found that some of the un-banked piggybacked on the bank accounts of other individuals to receive remittances.

\section{Informal Remittance Channel}

The money changer or bureau de change provides a generally safe and more affordable and convenient alternative to the formal remittance channel. It charges a flat rate for any amount transferred. Currency exchange rates can be negotiated which better educated workers tend to do. Rates vary between money changers and this can be from RM10 - RM25. Transfers are made in one - two days. The sender writes a letter to the recipient which the recipient has to provide to the corresponding money changer to collect the funds. Rates tend to be more competitive in Kuala Lumpur city than in towns. Most of these money changers cluster in areas where there is a heavy presence of migrant workers from different countries. Their operations remain open after office hours and on weekends. Factory workers who have long shifts will be able to take advantage of these longer operating hours. Partner money changers in Aceh provide a crucial link in this channel. This is because they provide additional community services such as physically depositing funds into the recipient's bank account or actually delivering the funds to the recipient's front door step. Based on interviews, there has been no case of theft or fraud using this 2 Kontan-Online No.34 Tahun IX 30/5/04

service. As such this is the most popular service chosen by the interview respondents. The riskiest type of informal channel is remittances via friends and relatives. This service is used by workers who financially cannot afford to come home often, do not have permission from their employers to take a leave of absence or do not want to be arrested by immigration officials. Friends or relatives take turns to return to the village for visits. But if the remittances are not urgently required, then the migrant worker will bring them home for Idul Fitri after the month of Ramadan. Remittances are sent in the form of cash, clothes and consumer goods (TV sets, fridges, rice cookers, etc). Based on interviews, there was a low incidence of friend or relatives 
stealing the remittances. Instead there was a higher incidence of the remittances being confiscated by customs officials in Indonesia. But over time according to respondents, migrant workers were becoming more aware of safer channels to use.

Another informal option though rare is provided by the taikong. This individual functions as the employer and remittance agent of the migrant worker. For a fee, the taikong will ensure that the remittances are delivered to the front door step of the recipient.

\section{Migration and Remittances Patterns before and after the Tsunami}

Before the tsunami, the formal and informal remittance channels were well developed and functioned well. Formal migrant workers could choose between the two channels. Informal workers could use a combination of the two - the sender without a bank account could use a money changer to transfer funds to his / her family's bank account. Respondents explained that families try to ensure that there is one bank account for use by the whole family. Normally it is the head of the family who has the bank account and everyone else piggybacks on it.

Based on interviews with Acehnese families, remittances are mostly used to support aged parents. This is because of the importance of filial piety in Acehnese values. The next priority is to use remittances to help pay for the family's basic needs which includes school fees at the primary and secondary school level. In dollar value, basic needs in Aceh are equivalent to Rp800000 or approximately US\$80/month3. Housing which would have been expected to be a priority was not 3 Based on calculations by PUGAR - The Center for People Movement \& Democracy, Aceh

as important to them as most of them had some form of housing and easy access to public, communal or privately owned land. Remittances are normally only sent after the first year of work in Malaysia or Singapore. Hence this diversified source of household income does not produce immediate returns. This is especially true for workers who have to repay recruitment fees to the calo. On occasion the worker may be fortunate to have entered Malaysia or Singapore illegally using his / her social network. Because of solidarity based on kinship, there are no fees to pay.

Amounts sent tend to be stable because most migrant workers aim for self-sufficiency 4 and have a fixed cost structure that covers in the following order of priority - debt repayment, living expenses and remittances. The percentage that can be saved for remittances is fixed. Based on interviews, the remittance patterns are: 
Table 2

\begin{tabular}{|l|l|l|l|}
\hline Sender & Recipient & $\begin{array}{l}\text { Amount Per Year } \\
\text { (US\$ equivalent) }\end{array}$ & Frequency \\
\hline $\begin{array}{l}\text { Father and } \\
\text { breadwinner }\end{array}$ & Wife \& children & $400-530$ & $\begin{array}{l}\text { Once a month, every } \\
\text { other month, 4x a year }\end{array}$ \\
\hline Son & Parents & $0-200$ (subsidy) & $\begin{array}{l}\text { Upon parents' request, } \\
\text { once a month, 4x a } \\
\text { year }\end{array}$ \\
\hline Daughter & Parents & $50-300$ (subsidy) & $\begin{array}{l}\text { Upon parents' request, } \\
\text { once a month, every } \\
\text { other month }\end{array}$ \\
\hline Daughter & Widowed Mother & 120 (subsidy) & 4x a year \\
\hline Brother & Parents and siblings & $20-500$ & Once a year \\
\hline Brother & Brother & $0-$ minimal amount & $\begin{array}{l}\text { Upon brother's } \\
\text { request }\end{array}$ \\
\hline
\end{tabular}

4 This was verified by the internal records of Western Union for its Asia market

Given these patterns of intra-household allocation, there is a degree of predictability in the remittance pattern and there is stability in the amounts sent. Predictability increases when the sender is the father and head of the family. Fathers interviewed that by sending money every month, they felt assured that all expenditures could be paid. They did not have to worry about their wives having to manage finances. Also predictability increases when the recipient is an aged or widowed parent. But as observed in Table 2, predictability decreases when the sender is not the head of the family. It was also found that if the sender had many siblings who had jobs, there was even less priority to send remittances. Young migrant workers interviewed especially men who were unmarried were more inclined to use their income as savings for future investment in Aceh. Daughters were found to be extremely responsible for the widowed mothers' welfare.

Hence with reference to table 2 and the interview responses, remittances are of the greatest benefit to aged parents and widowed mothers, followed by the worker's wife and children. Remittances play a social protection role for these groups. However parents tend to receive remittances as subsidies while the wife and family tend to be fully covered. Remittances are of least benefit to the worker's siblings.

Concerning the use of money changers, many respondents found their services to be reliable. This was confirmed by the money changers who became familiar with their customers and knew which village the recipients lived in. As such, predictability in the remittance pattern increases and amounts sent remain stable.

At the macro-level, these remittances can be described as unpredictable because households receive different amounts at different frequencies. But according to Pos Indonesia, each year, there is a guaranteed spike in the value of amounts sent to all of Indonesia a few days prior to the Idul Fitri celebrations. Based on the limited data accessed from Pos Indonesia, remittances sent 
the rest of the year are stable with the exception of a 300\% spike for Idul Fitris. Hence in general, the remittance trend appears to be:

${ }_{5}$ Kantor Pos Purwokerto ; www.posindonesia.co.id

\section{Chart 1}

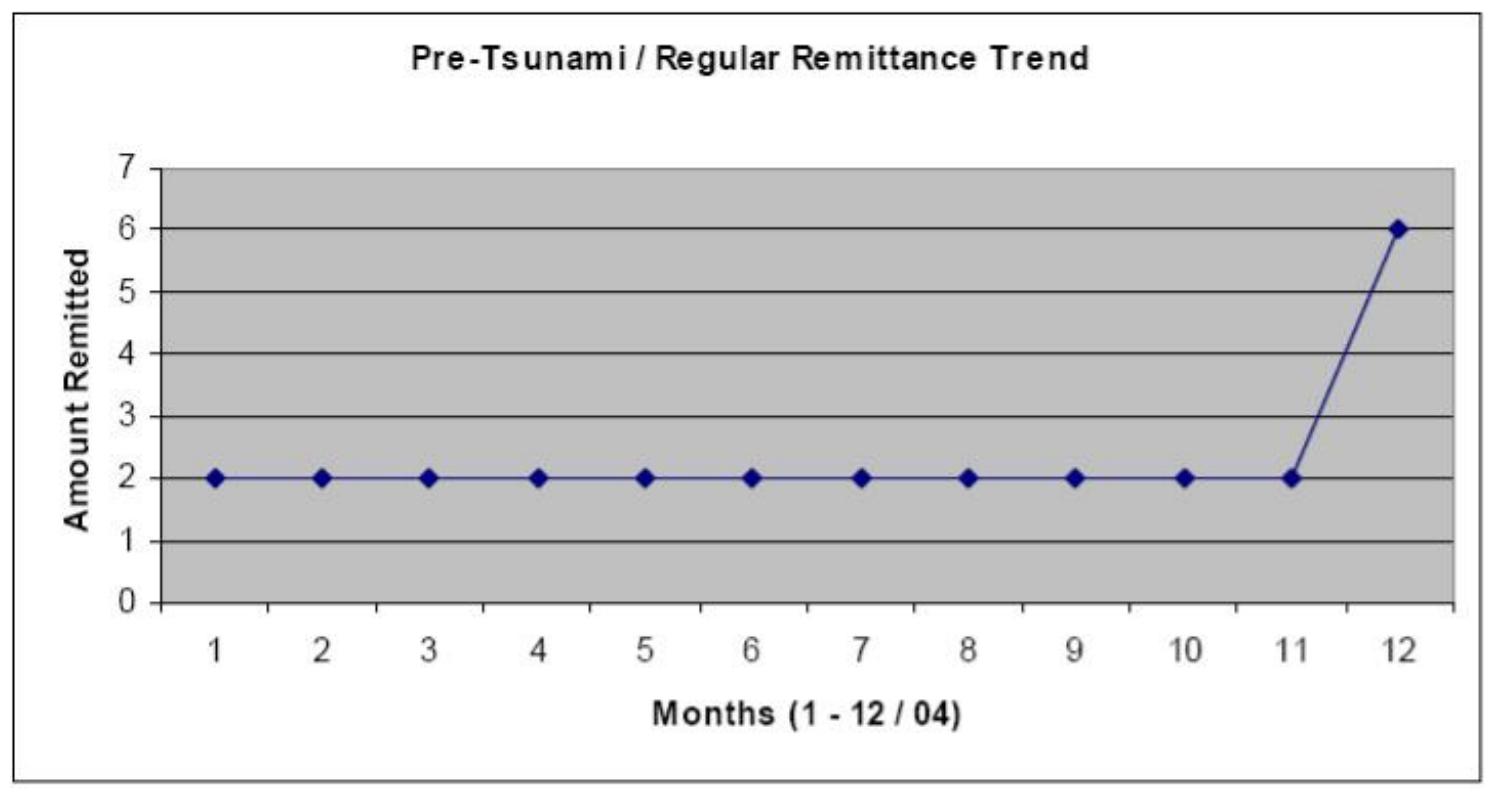

After the tsunami, the question then is how this remittance trend changed.

Based on interviews, in the first month after the tsunami, many migrant workers could not locate their families. Family members either died or were displaced. These workers took $14-30$ days to locate their families using mobile phones (calls and SMS text messages) to contact friends and relatives. After locating them, there were more workers who could not return to care for their families in the emergency period than those who could. This was because of several reasons - the worker had just started his / her first year of work in Malaysia and Singapore and had to use all of his / her income to repay the calo; the worker had entered the destination country illegally and could not risk arrest by leaving to return to Aceh; the worker did not receive permission for a leave of absence from the employer or most family members had died including the parents and it was pointless to return to care for a surviving sibling.

A respondent who managed to return located her entire family in an IDP camp. She said that she returned with a plane load of other workers. This was in the beginning of February 2005. She was fortunate to receive a leave of absence from her employer for a month. In addition her employer made a charitable contribution of RM1000 or approximately US\$266. She brought home money, food, clothes and gifts to help her family especially her widowed mother through the emergency period. For the whole month, she stayed with her family in the camp. She was very thankful for the foreign aid assistance that they had received in the camp because it alleviated her burden. By the time she left, her family had returned to rehabilitate their partly damaged home.

There was also a respondent who had a sister who flew from Malaysia to Aceh two weeks after the tsunami. She used to frequently send remittances to her family. But since starting her own family in Malaysia, she sent less money and tended to focus on her mother's needs. In the 
aftermath of the tsunami, she ensured that her mother was re-located to a relative's house and had sufficient funds, food, medicine and clothes. She did not provide any assistance to her brother. She expected her brother who lived in Banda Aceh to be self-sufficient.

There is another case where there is less concern for a sibling. A young motorized rickshaw or becak driver who was interviewed reported that after his parents and eight family members died in the tsunami, his older brother who had settled permanently in Malaysia decided to stop sending regular remittances. This young respondent was expected to be self-sufficient as his older brother struggled to get by in Malaysia. On rare occasions his brother would send some money.

For migrant workers who wanted to return but couldn't and had some savings, emergency remittances were sent via friends and relatives. According to six respondents (either worker who couldn't return or family of workers who couldn't return) amounts sent were the same as pretsunami.

In addition, according to a migrant worker union organizer, the union had a fund raising campaign to supplement the remittances of workers. These charitable contributions were pooled and distributed by community based organizations (CBOs) using their social networks and by emergency and relief aid agencies. But this union organizer acknowledged that the union could not individually supplement a worker's private remittances. Other respondents confirmed that there was a significant level of charitable contributions. This implies that these contributions either supplemented or substituted for remittances.

Emergency and relief aid and community CBO distribution of goods and cash (through cash transfers, grants and cash-for-work) to IDPs were reportedly extremely important during the emergency. This was especially so in geographically isolated areas where such distribution was an alternative to regular channels. Both the formal and informal remittance channels were badly affected by the tsunami. Corresponding banks for remittances and infrastructure were destroyed or severely damaged. Only two banks on the east coast of Aceh were operational by the first week of January 2005 (Kompas, 31/12/2004). BII was operational by 14 January, 2006. Although Western Union was operational within 24 hours of the tsunami it had a limited coverage because its agents such as the above mentioned banks had suspended operations. Money changers were only operational $1-2$ weeks after the tsunami. However Pos Indonesia still managed to function by redirecting its work load away from the damaged areas in Aceh to Jakarta and Medan. Correspondingly according to the Bank Republik Indonesia, total remittances received by the country for January - February 2005 was Rp. 177,680 million, down 7.34\%. This figure did not include remittances using informal channels. As such it could be strongly inferred that the reduction was even more significant during the emergency period.

Although these remittance channels tried to be operational as soon as possible, the main problem that many migrant workers faced was that they could not provide an address for where their families were re-located to. A mailing address is needed by WU, Pos Indonesia and money changers in order for contact to be made with the rightful recipient. The use of a mailing address to identify a recipient is an institutionalized practice in both formal and informal channels because many recipients from poor rural households do not have identification papers. This situation was exacerbated by the tsunami when those who did have identification papers lost them in the disaster.

The problem of the mailing address becomes significant given efforts by formal remittance sending companies to promote more transfers during the emergency period. Singapore Post (Sing 
Post) announced a commission waiver of the remittance service to the tsunami hit areas. This waiver was effective from 14 January - 31 January 2005. On behalf of Western Union, Sing Post also announced that a reduced and flat rate of $\$ 12$ (or US\$7.6) was charged for remittances to any of the tsunami affected countries. Transfer amounts could not exceed S\$1000 (or US\$131). This was valid from 14 January 2005 - 10 February 2005. But when asked whether the commission waiver increased remittance dollar amounts or volume of transactions, Sing Post responded that the trend remained stable and unchanged during this period.

Using the only accessible January - February 2005 official figures from the Bank Republik Indonesia and Sing Post, it can be strongly inferred that many IDPs had their remittances disrupted and had to rely on foreign emergency and relief aid and CBOs. But by February March 2005, the remittance patterns started to recover. This may have been motivated the most by the network of money changers. According to a key player in the currency exchange business, they took the initiative to put in place an emergency communications system using the flexsi local mobile phone network which had limited coverage of a seven $\mathrm{km}$ radius from each main town in each district. Using this system, they could help migrant workers contact their families. Locations of IDP camps could then be provided to the money changers. They would make arrangements to either deliver the funds to functioning bank accounts that the IDPs piggybacked on or sometimes even make deliveries to the camps.

By mid-2005, respondents observed that more migrant workers were returning to Aceh bearing money and gifts. By end-2005, remittance systems both formal and informal were operating at a higher capacity for Idul Fitri celebrations in November. This suggests that by mid-2005 as Aceh entered the relief and rehabilitation phase, families were using aid assistance and remittances side-by-side or in a complementary manner.

In comparing the remittance trend before and after the tsunami, it appears that the difference was a severe reduction in the flow of funds during the emergency phase. But by mid-2005, remittance levels increased and perhaps to normal levels. According to Pos Indonesia, the number of remittance transactions for all of Indonesia increased by a rate of $2 \mathrm{x}$ leading up to the first Idul Fitri after the tsunami (Tempo, 31/10/05). According to a woman interviewed in Tanjung Daya, Aceh Besar, she was looking forward to moving into her new house and celebrating Idul Fitri. When asked why some of her neighbors still had not moved into their homes, she said that the women could not afford to furnish their homes. When asked how she could afford to furnish her home albeit at increased prices because of the festive season, she said that it was because she had received money from relatives. This implies that even though there is pressure for foreign aid agencies to quickly build homes for the IDPs, it may be remittances that help families with the financial nudge to move into those newly built homes.

Based on the triangulation of data concerning remittances post-tsunami, the trend changed to become: 
Chart 3

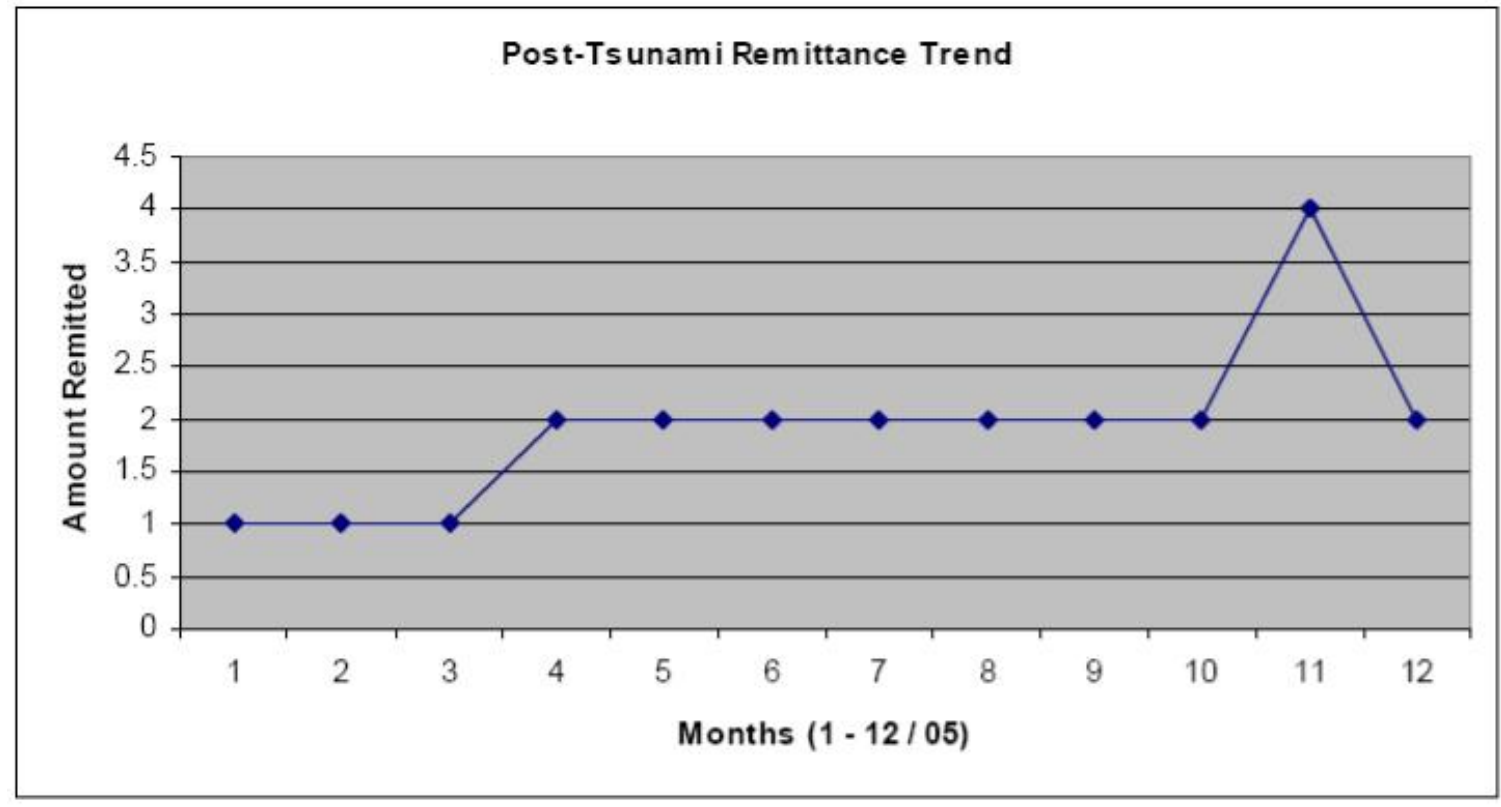

In comparing charts 2 and 3, the remittance flows were severely affected in the first three months of the emergency. Alternative distribution channels were needed to help families cope.

Emergency assistance was needed. But by April or the fourth month, private arrangements for remittances using the various channels resumed. There was less need for external intervention. Apart from the changes to the remittance trends associated with the tsunami, there were changes to the migration trend.

Two young men who worked in casual labor were interviewed in an IDP camp in Lancung Paru, Pidie. They were permanent returnees from Malaysia. Both had returned after the tsunami - one had returned in August and the other in November to celebrate Idul Fitri. They did not return sooner to their village of origin because the transportation links had been badly damaged by the tsunami. The reason for their return was that they could not find any stable employment. They moved in with their families in the camps who were registered as aid beneficiaries and wanted to take advantage of the recovery process.

A young woman who was a domestic worker was interviewed in her home in Meulaboh. She had returned immediately after the tsunami had hit to look for survivors. When she feels that her family no longer needs her assistance and if she cannot start up her own baking business with funding from an aid agency, she will return to Malaysia to continue working as a domestic worker for the same employer.

In Selayang, Malaysia a respondent who had left Aceh after the tsunami for fear of being pursued by TNI said that he was also planning to return to Aceh. But his reason for returning is to support political reform in response to the RI-GAM peace agreement.

It appears that more unskilled migrant workers are returning to Aceh to assess economic opportunities in the recovery process. 12 individuals interviewed of which four were IDPs identified themselves as migrant workers to Malaysia and were all assessing the costs and benefits of returning to Aceh temporarily or permanently. They reported that many workers had 
returned from Malaysia in November to celebrate Idul Fitri and after the holidays would

determine whether to stay on. These IDPs interviewed had short-term work contracts in Malaysia.

\section{Conclusions}

After the tsunami, remittances could not help families to cope with the crisis during the first two to three months. Daily needs normally financed by remittances could not be met. Families needed cash and in-kind relief assistance from emergency and relief aid agencies. This finding provides some support for this paper's hypothesis that diversified sources of income does not necessarily reduce household vulnerability conditional on the magnitude of a disaster.

Remittance flows then recovered and peaked during Idul Fitri. Some amount of reverse migration occurred because of the RI-GAM peace agreement. Given this situation, emergency assistance should substitute for remittances in the short term and be complementary in the longer term with local efforts to cope with risk; this is until the full resumption of government provision of goods, services and income transfers.

The demographic and socio-economic profiling of the migrant worker member within a household is an important factor for identifying vulnerability. Better educated female migrant workers with formal contracts originating from the districts of Pidie and Bireun and Lhoseumawe town appear to provide the most predictable remittance flows. Less educated, conflict affected male workers who work illegally, are apparently most vulnerable to remittance disruptions.

Although in an emergency all families of migrant workers require the same amount of assistance, it is more likely that given the above female worker profile, her family will bounce back faster. The relationship between the sender and recipient is another important factor for consideration in determining income transfers. If the family member who died in the tsunami was an aged parent, wife or child, the migrant worker may no longer have the motivation to send remittances. As a consequence the younger sibling(s) of the worker may be left alone without support. In this case, the unitary household model assumption fails to hold.

The resumption of remittance services in Aceh is surprisingly fast and the transactions carried out are efficient. This is because of the well-entrenched social network. Hence for policymaking, there should be an analysis of how quickly private decision making and transactions by families can resume without or in parallel with external assistance.

This paper has shed some light on one of the types of households that is most vulnerable to the risk of disasters and how income flows between members in this household. This type of household has the following characteristics: 1) living below the poverty line, 2) with up to three generations in the household composition and 3) consisting of at least one family member who is a migrant worker. Individual and household behavior after a disaster reported here challenges conventional wisdom on what a vulnerable household might look like because of disasters. However it is specific to the Acehnese community. Similar case studies using the intra-household allocation approach should be applied to other areas of disasters. This will help to better translate the concepts of household vulnerability to different conditional expectations. 


\section{Bibliography}

Asian Development Bank “Regional Technical Assistance No. 6212: Southeast Asia Workers' Remittance Study"

Becker, Gary S. A Treatise on the Family, Cambridge: Harvard University Press, 1991 Hugo, Grame J, "Circular Migration in Indonesia" in Population and Development Review 8, No. 1, March 1982

Glewwe, Paul and Hall, Gillette "Are some groups more vulnerable to macroeconomic shocks than others? Hypothesis tests based on panel data from Peru" in Journal of Development Economics Vol. 56 (1998) 181 - 206

Jones, Sidney "Hope and Tragedy for Migrants in Malaysia" in Asia-Pacific Magazine No.1 April 1996 pp. 23-27 or http://coombs.anu.edu.au/asia-pacific-magazine

Keban, Yeremias T. "International Migration, the Strategy for National Development and Globalization in Labor Migration in Indonesia: Policies and Practices editors Sukamdi, Abdul Haris and Patrick Brownlee; Yogyakarta: Population Studies Center Gadjah Mada University, 1998

Lazear, Edward P. and Michael, Robert T. Allocation of Income Within the Household, Chicago: The University of Chicago Press, 1988

Lucas, Robert “International Migration and Economic Development: Lessons from Low Income Countries"Stockholm: Ministry for Foreign Affairs Sweden, 2005

Mantra, Ida Bagoes "Indonesia Labor Mobility to Malaysia" in Labor Migration in Indonesia: Policies and Practices editors Sukamdi, Abdul Haris and Patrick Brownlee; Yogyakarta: Population Studies Center Gadjah Mada University, 1998

Nasution, M. Arif "International Migration in South East Asia: a Case Study of Indonesian Workers in the Malaysian Peninsular in Labor Migration in Indonesia: Policies and Practices editors Sukamdi, Abdul Haris and Patrick Brownlee; Yogyakarta: Population Studies Center Gadjah Mada University, 1998

Spaan, Ernst "Taikongs and Calos: The Role of Middlemen and Brokers in Javanese International Migration" in International Migration Review, Vol. 28, No.1. (Spring, 1994), pp. 93-113.

Wong, Diana and Teuku, Afrisal "Migran Gelap. Indonesian Migrants into Malaysia's Shadow Economy” unpublished manuscript submitted to Scalabrini Migration Center: Manila, 2002

Wu, Treena "Nutrition Evaluation of Acehnese, Burmese and Thai Refugees in Malaysia" unpublished manuscript submitted to ACTS Malaysia, 2006

Wu, Treena "Evaluation of Beneficiary Accountability in Aceh: Communications \& Feedback" commissioned by Oxfam International, 2005 


\section{Maastricht Graduate School of Governance Working Paper Series}

\section{List of publications}

\begin{tabular}{lll}
$\begin{array}{l}\text { 2006 } \\
\text { No. }\end{array}$ & Author $(s)$ & Title \\
\hline 001 & $\begin{array}{l}\text { Gassmann, F. and } \\
\text { G. Notten }\end{array}$ & $\begin{array}{l}\text { Size matters: Poverty reduction effects of means-tested and } \\
\text { universal child benefits in Russia }\end{array}$ \\
\hline 002 & $\begin{array}{l}\text { Hagen-Zanker, J. } \\
\text { and } \\
\text { M.R. Muñiz Castillo }\end{array}$ & $\begin{array}{l}\text { Exploring multi-dimensional wellbeing and remittances in } \\
\text { El Salvador }\end{array}$ \\
\hline 003 & Augsburg, B. & $\begin{array}{l}\text { Econometric evaluation of the SEWA Bank in India: } \\
\text { Applying matching techniques based on the propensity } \\
\text { score }\end{array}$ \\
\hline 004 & $\begin{array}{l}\text { Notten, G. and } \\
\text { D. de Crombrugghe ( }\end{array}$ & \begin{tabular}{l} 
Poverty and consumption smoothing in Russia \\
\hline
\end{tabular} \\
\hline
\end{tabular}

\section{7}

\begin{tabular}{|c|c|c|}
\hline No. & Author(s) & Title \\
\hline 001 & $\begin{array}{l}\text { Notten, G. and C. de } \\
\text { Neubourg }\end{array}$ & $\begin{array}{l}\text { Relative or absolute poverty in the US and EU? The battle } \\
\text { of the rates }\end{array}$ \\
\hline 002 & $\begin{array}{l}\text { Hodges, A. A. } \\
\text { Dufay, K. Dashdorj, } \\
\text { K.Y. Jong, T. } \\
\text { Mungun and U. } \\
\text { Budragchaa }\end{array}$ & $\begin{array}{l}\text { Child benefits and poverty reduction: Evidence from } \\
\text { Mongolia's Child Money Programme }\end{array}$ \\
\hline 003 & $\begin{array}{l}\text { Hagen-Zanker, J. } \\
\text { and Siegel, M. }\end{array}$ & The determinants of remittances: A review of the literature \\
\hline 004 & Notten, G. & $\begin{array}{l}\text { Managing risks: What Russian households do to smooth } \\
\text { consumption }\end{array}$ \\
\hline 005 & $\begin{array}{l}\text { Notten, G. and C. de } \\
\text { Neubourg }\end{array}$ & $\begin{array}{l}\text { Poverty in Europe and the USA: Exchanging official } \\
\text { measurement methods }\end{array}$ \\
\hline 006 & $\begin{array}{l}\text { Notten, G and C. de } \\
\text { Neubourg }\end{array}$ & $\begin{array}{l}\text { The policy relevance of absolute and relative poverty } \\
\text { headcounts: Whats in a number? }\end{array}$ \\
\hline 007 & $\begin{array}{l}\text { Hagen-Zanker, J. } \\
\text { and } M \text {. Siegel }\end{array}$ & $\begin{array}{l}\text { A critical discussion of the motivation to remit in Albania } \\
\text { and Moldova }\end{array}$ \\
\hline 008 & Wu, Treena & $\begin{array}{l}\text { Types of Households most vulnerable to physical and } \\
\text { economic threats: Case studies in Aceh after the Tsunami } \\
\text { (Theme 2) }\end{array}$ \\
\hline
\end{tabular}

\section{8}

\begin{tabular}{lll} 
No. & Author $(s)$ & Title \\
\hline 001 & $\begin{array}{l}\text { Roelen, K. and } \\
\text { Gassmann, F. }\end{array}$ & $\begin{array}{l}\text { Measuring Child Poverty and Well-Being: a literature } \\
\text { review }\end{array}$
\end{tabular}

